\title{
Correlation between Triglyceride/HDL Ratio with Severity of Coronary Artery Lesion in Non-Diabetic Stable Angina Pectoris Patients
}

\author{
Pramon Aditya Sudjana*, Chaerul Achmad, Achmad Fauzi Yahya, Januar W. \\ Martha, M. Rizki Akbar
}

Department of Cardiology and Vascular Medicine, Hasan Sadikin Hospital, Bandung, Indonesia

\author{
${ }^{*}$ Corresponding author: \\ Pramon Aditya Sudjana MD., - email: pramonsudjana@gmail.com \\ Address: Cardiac Center $7^{\text {th }}$ floor, Hasan Sadikin Hospital, Jalan Pasteur No. 38, Bandung, West Java 40161, Phone: \\ +6222-2551111, Indonesia
}

Manuscript submitted: August 24, 2018; Revised and accepted: October 4, 2018

\section{ABSTRACT}

Background: Triglycerides (TG) as a risk factor for coronary artery disease (CAD) is still a matter of controversy but when used as a single ratio with high density lipoprotein (HDL) the predictive value for CAD is better. The TG/HDL ratio is also associated with the presence of small dense LDL (sdLDL) in the body. SdLDL is a more atherogenic LDL subfraction and has been proven to be associated with CAD progression.

Aims: This study aims to find the correlation between the TG/HDL ratio and the degree of coronary lesion severity based on the Gensini score in stable non diabetic angina pectoris patients.

Methods: This study was a cross sectional study conducted at Dr. Hasan Sadikin Hospital and Hasna Medika Palimanan Hospital. Subjects were non diabetic stable angina pectoris patients $\geq 18$ years old who underwent elective coronary angiography. Blood collection for TG and HDL examination was performed after coronary angiography. Gensini scoring system was used to assess the severity of coronary lesions. The relationship between the TG/HDL ratio and the Gensini score was analyzed using multiple linear regression tests against confounding variables.

Results: This study involved 60 patients with stable angina pectoris with a mean age of $60 \pm 8$ years. The mean TG/HDL ratio is $2.56 \pm 1.04$. The average Gensini score was $51 \pm 36$. The $\mathrm{TG} / \mathrm{HDL}$ ratio was significantly associated with the Gensini score $(R=0.637 ; p<0.001)$. Analysis of confounding variables showed age, hypertension, and metabolic syndrome had a weak correlation with Gensini score ( $r$ values of $0.321,0.270$, and $0.333, p<0.05$, respectively), while those correlating with TG/HDL ratios were men, hypertension, and metabolic syndrome ( $r$ values of $0.290,0.287$, and $0.362, p<0.05$, respectively).

Conclusion: TG/HDL ratio was significantly positively correlated significantly with the severity of coronary lesions based on Gensini score in non diabetic stable angina pectoris patients.

Keywords: stable angina pectoris; TG / HDL ratio; small dense LDL; severity of coronary lesions; Gensini

\section{INTISARI}

Latar belakang: Trigliserida sebagai factor risiko PAK masih menjadi kontroversi akan tetapi ketika dijadikan rasio tunggal bersama HDL maka nilai prediktifnya untuk PAK menjadi lebihbaik. Rasio TG/HDL juga berhubungan dengan adanya small dense LDL dalam tubuh. SdLDL merupakan subfraksi LDL yang lebih aterogenik dan telah terbukti berhubungan dengan progresifitas dari CAD.

Tujuan : Penelitian ini bertujuan untuk mencari korelasi antara rasio TG/HDL dengan derajat keparahan lesi koroner berdasarkan skor Gensini pada penderita angina pectoris stabil non diabetik.

Metode : Penelitian ini merupakan penelitian potong lintang yang dilakukan di RSUP dr. Hasan Sadikin Bandung dan RS Hasna Medika Palimanan. Subjek penelitian adalah penderita APS stabil non diabetic $\geq 18$ tahun yang menjalani angiografi koroner elektif bulan Juni-Agustus 
2018. Pengambilan darah untuk pemeriksaan trigliserida dan HDL dilakukan setelah tindakan angiografi koroner. Penilaian derajat keparahan lesi koroner dilakukan menggunakan system scoring Gensini. Hubungan antara rasio TG/HDL dengan skor Gensini dianalisis menggunakan uji regresi linear berganda terhadap variable perancu.

Hasil : Penelitian ini melibatkan 60 penderita APS dengan rata-rata umur $60 \pm 8$ tahun. Ratarata rasio TG/HDL adalah 2,56 $\pm 1,04$. Rata-rata skor Gensini adalah $51 \pm 36$. Ratio TG/HDL berhubungan dengan skor Gensini secara bermakna $(R=0,637 ; p<0,001)$. Analisis terhadap factor variable perancu menunjukkan usia, hipertensi, dan metabolic sindrom memiliki korelasi lemah dengan skor Gensini (nilai r masing-masing 0,321, 0,270, dan 0,333, p<0,05), sedangkan yang berkorelasi dengan rasio TG/HDL yaitu jenis kelamin laki-laki, hipertensi, dan sindroma metabolik (nilai $r$ masing-masing 0,290, 0,287, dan 0,362, $p<0,05$ ).

Kesimpulan: Rasio TG/HDL berkorelasi positif kuat secara bermakna terhadap derajat keparahan lesi koroner berdasarkan skor Gensini pada penderita APS non diabetik.

\section{INTRODUCTION}

Coronary artery disease (CAD) is still a global health problem and the incidence continues to increase.CAD causes 1.8 million deaths annually and $20 \%$ causes of overall death in Europe while in the United States it is the main cause of death and responsible for 1 in 4.8 deaths. ${ }^{1,2}$ The incidence of CAD in developing countries is expected to continue to double by $2020 .^{3}$

At first triglycerides was considered as a CAD risk factor but studies after that failed to support this idea. Interest in triglycerides reappears after studies in these recent years show that if triglycerides was used as a single ratio with HDL, their strength to predict CAD is better. This is caused by TG/HDL ratio is associated with the presence of small dense LDL (sdLDL) in the body. SdLDL is a more atherogenic LDL subfraction and has been shown to be associated with the progression of CAD.

Research about the relationship of $\mathrm{TG} / \mathrm{HDL}$ ratio with severity of coronary artery lesions in CAD patients has been done but the severity of coronary artery lesions in these studies was assessed using the friesinger index and local scoring system in local hospitals while those using Gensini score had already been carried out but in the stable CAD and acute coronary syndrome (ACS) population.

\section{METHODS}

Study population

A total of 80 consecutive angina pectoris patients admitted to the hospital between June-August 2018 who underwent coronary angiography upon referral to catheterization laboratory in Hasan Sadikin and Hasna Medika hospitals were included in this cross-sectional study. Patients aged over 18 years were included in the study, whereas patients with diabetes mellitus, history of bypass surgery, history of PCI, and renal dysfunction were excluded.

Written informed consent was obtained from each subject following a detailed explanation of the objectives and protocol of the study, which was conducted in accordance with the ethical principles stated in the "Declaration of Helsinki"; this study was approved by the institutional ethics committee.

\section{Study parameters}

The clinical variables included patient demographics (age, gender), traditional risk factors for atherosclerosis (hypertension and smoking), physical exercise, use of statin, metabolic syndrome,physical exam (height, weight,blood pressure), and the blood biochemistry of the lipid parameters (HDL-C and triglycerides)

Coronary Angiography and the Gensini $\underline{\text { Score }}$

Coronary angiography was performed for the patients with stable angina pectoris or a positive cardiac stress test. Selective coronary cineangiography was performed through the radial or femoral approach using the Judkins technique and a General Electric angiographic system. Multiple views were recorded for all the patients. Significant stenosis was determined visually and was defined as a reduction in the lumen diameter by $\geq 50 \%$ in any view compared to the nearest normal segment. CAD severity was assessed using the Gensini score. The Gensini score was 
computed by assigning a severity score to each coronary stenosis according to the degree of luminal narrowing and its geographic importance. Reduction in the lumen diameter and the roentgenographic appearance of the coronary artery lesion were evaluated as 1 for $1-25 \%$ stenosis, 2 for $26-50 \%$ stenosis, 4 for $51-75 \%$ stenosis, 8 for $76-90 \%$ stenosis, 16 for $91-$ $99 \%$ stenosis and 32 for total occlusion. The score is then multiplied by a factor that represents the importance of the lesion's position in the coronary arterial system. For example, 5 for the left main coronary artery, 2.5 for the proximal left anterior ascending or proximal left circumflex artery, 1.5 for the mid-region, and 1 for the distal left anterior descending or mid-distal region of the left circumflex artery.

\section{Statistical Analysis}

The statistical analyses were performed using computer software (SPSS version 21.0, SPSS Inc. Chicago, IL, USA). This study uses three approaches for data analysis that are univariate analysis, bivariate analysis and multivariate analysis. For numerical data, the data distribution tested using the Kolmogorov-Smirnov method because sample size $>50$. Data that is normally distributed in the univariate analysis are expressed in mean and standard deviation, while data with abnormal sample distribution are expressed in median with range. Categorical data expressed in frequency and percentage. Bivariate analysis is carried out after the univariate analysis to see the relationship between two variables. If the variables shows normal data distribution then bivariate analysis is done using Pearson correlation and if it is not normal Spearman rank were used. The dependent variable data (Gensini score) is numerical data, so multiple linear regression analysis were used for multivariate analysis. In multiple linear regression analysis, there are simultaneous tests (using F test) and partial test (using $t$ test). The $p$ value is less than 0.05 that considered statistically significant.

\section{RESULTS}

The study sample comprised 80 patients (mean (SD) age: $60 \pm 8$ years, $71.1 \%$ male). Of the total 80 patients, 20 patients were excludes because 7 patients had diabetes melitus, 9 patients had history of $\mathrm{PCl}, 2$ patients had history of bypass surgery, and 2 patients had no coronary lesions. Median for BMI was 24.23 (17.63$39.67) \mathrm{kg} / \mathrm{m}^{2}$ with 7 patients included in obese group. The most prevalent traditional risk factor for CAD was hypertension $(66.7 \%)$. For statin consumption, $18.3 \%$ of patients took high-intensity statins, $13.3 \%$ took medium-intensity statins, $18.3 \%$ took low-intensity statins, and $50 \%$ did not take statins. Triglyceride and HDL levels had a median and a range of 114 (48 - 283) $\mathrm{mg} / \mathrm{dL}$ and $47(27-85) \mathrm{mg} / \mathrm{dL}$ with a $\mathrm{TG} / \mathrm{HDL}$ ratio having an average of $2.56 \pm$ 1.04. The Gensini score has an mean of 51 \pm 36 .

Because the data distribution from the TG/HDL ratio and Gensini score showed a normal distribution, bivariate analysis was performed using Pearson correlation. Bivariate analysis was also carried out on confounding variables by using Spearman rank and biserial point correlations. TG/HDL ratio $(r=0.765$, $\mathrm{p}<0.001), \quad$ age $\quad(r=0.321, \quad \mathrm{p}=0.012)$, hypertension $(r=0.270, \quad p=0.037, \quad$ and metabolic syndrome $(r=0.333, p=0.009)$ were found to have correlation with Gensini score. For the multivariate analysis the confounding variables included in multiple linear regression are those that have significant values $(p<0.25)$ in the bivariate analysis of the dependent variables, namely the TG/HDL ratio, age, male sex, hypertension, obesity, and metabolic syndrome. The results of multiple linear regression analysis showed that there was a positive correlation between the TG/HDL ratio and Gensini score which was significant with $r=0.765, p<0.001$ before being controlled by confounding variables and $r=0.637, p<0.001$ after being controlled by confounding variables. The determinant coefficient value $R^{2}$ is 0.649 which means that the TG/HDL ratio after being controlled by confounding can explain the variability of the Gensini score by $64.9 \%$ while the rest is influenced by other factors. The TG/HDL ratio has a coefficient $\beta$ of 22.02 which means that every increase in the $\mathrm{TG} / \mathrm{HDL}$ ratio of 1 will increase the Gensini score of 22, after being controlled by confounding factors of age, hypertension, and metabolic syndrome. 
Table 1. Baseline characteristics

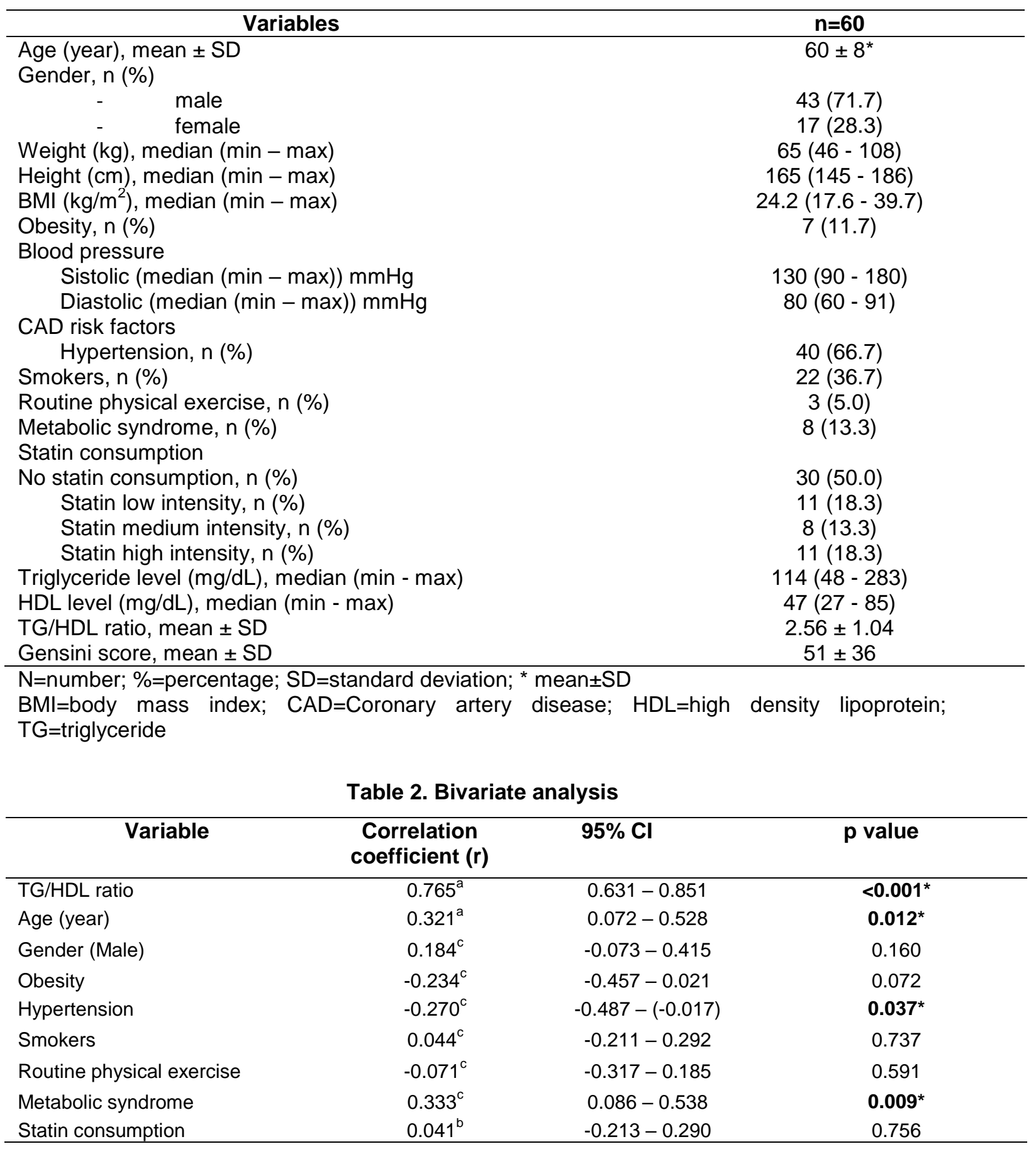

$\mathrm{Cl}=$ confidence interval; analysis using correlation ${ }^{a}$ Pearson, ${ }^{b}$ rank Spearman, ${ }^{c}$ point biserial, *statistically significant $p<0,05$ 
Table 3. Multivariate analysis

\begin{tabular}{lccccc}
\hline \multicolumn{1}{c}{ Variable } & \multicolumn{2}{c}{$\begin{array}{c}\text { Unstandardized } \\
\text { Coefficient }\end{array}$} & $\begin{array}{c}\text { Standardized } \\
\text { Coefficient }\end{array}$ & P value & $\mathbf{R}^{2}$ \\
\cline { 2 - 4 } & $\boldsymbol{\beta}$ & Std. Error & $\boldsymbol{\beta}$ & & \\
\hline Constanta & -45.163 & 21.671 & & $0.042^{*}$ & 0.649 \\
TG/HDL ratio & 22.025 & 3.610 & 0.637 & $<\mathbf{0 . 0 0 1}^{*}$ & \\
Age & 0.763 & 0.345 & 0.186 & $\mathbf{0 . 0 3 1 ^ { * }}$ & \\
Gender (Male) & -2.827 & 7.183 & -0.036 & 0.695 & \\
Hypertension & -4.316 & 6.574 & -0.057 & 0.514 & \\
Metabolic syndrome & 16.405 & 10.678 & 0.157 & 0.130 & \\
Obesity & -19.753 & 10.011 & -0.178 & 0.054 & \\
\hline
\end{tabular}

$\mathrm{R}^{2}=$ coefficient determination

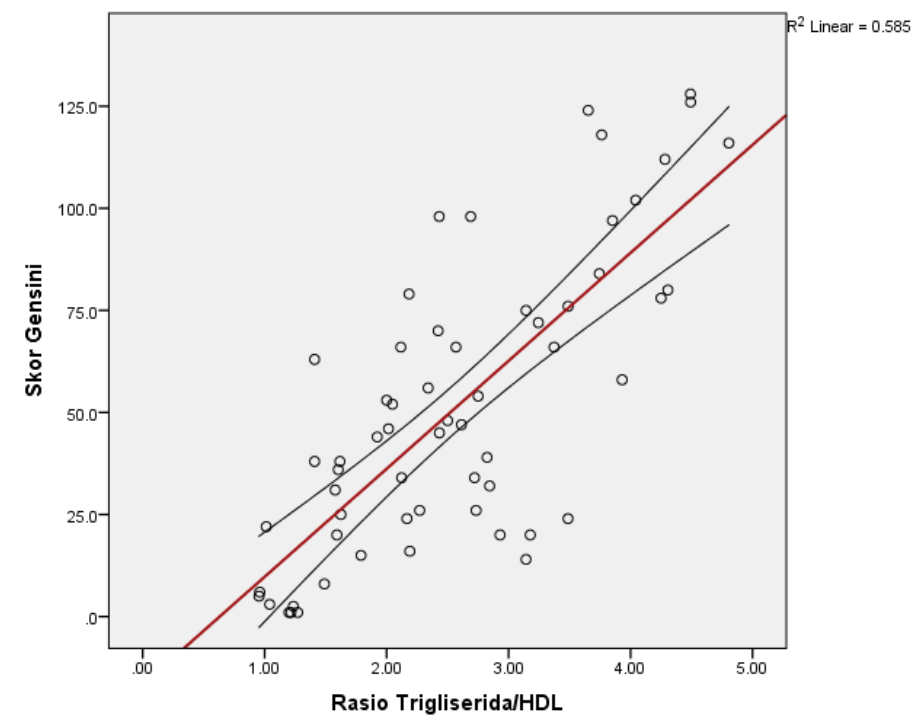

Figure 1. Scatter plot between TG/HDL ratio with Gensini score after Adjusted with Confounding

Variables

\section{DISCUSSION}

We found a relationship between the extent of coronary disease and TG/HDL ratio using bivariate analysis. In a multivariate model that included others confounding variables, the TG/HDL ratio was found to be a powerful independent indicator of extensive coronary disease. These results support previous studies by Ostfeld $\mathrm{R}$ et $\mathrm{al}^{4}$, Conkbayir $\mathrm{C}$ et $\mathrm{al}^{5}$, Da Luz et $\mathrm{al}^{6}$, and Hadaegh $\mathrm{F}$ et $\mathrm{al}^{7}$.

Hadaegh $\mathrm{F}$ et $\mathrm{al}^{7}$ conducted a study on male populations in Iran. In their study, the population was divided into 4 quartiles based on the TG/HDL ratio. Based on this study, the TG/HDL ratio, total cholesterol, age, systolic blood pressure, abdominal circumference, and DM were independent predictors for CAD. In contrast to this study, DM patients were excluded and after adjusted with confounding variables, the TG/HDL ratio still has a strong relationship with severity of coronary lesion.

A study conducted by Da Luz et al ${ }^{6}$ and Conkbayir $\mathrm{C}$ et al ${ }^{5}$ showed that the TG / HDL ratio was associated with the severity of coronary lesions assessed by using Friesinger index. Da Luz et al. ${ }^{6}$ showed TG/HDL ratio> 4 associated with the severity of coronary lesions. Both studies used stable angina pectoris patients as their study population and Conkbayir $\mathrm{C}$ et $\mathrm{al}^{5}$ excluded DM patients in their study.

Ostfeld $\mathrm{R}$ et $\mathrm{al}^{4}$ includeunstable angina pectoris patients as their study population. The degree of severity of coronary lesions is assessed using a 
scoring system developed at the health care center where the study was conducted. Based on this study, the $\mathrm{TG} / \mathrm{HDL}$ ratio $\geq 3.5$ was associated with the severity of coronary lesions.

Yang D et al ${ }^{8}$ study used Gensini scores for quantifying severity of coronary lesion with a population of stable angina pectoris and acute coronary syndrome patients. The study showed an LDL/HDL ratio, total cholesterol/HDL, and $\mathrm{TG} / \mathrm{HDL}$ associated with the severity of coronary lesions.

Lipid-lowering drugs are important to be used as confounding variables because it is possible that in one patient the lesions are extensive but the TG/HDL ratio is low because of the effects of lipidlowering drugs. Only one of the above studies that included lipid-lowering drugs as confounding variables which is study byOstfeld $\mathrm{R}$ et $\mathrm{al}^{4}$. Lipid-lowering drugs was made as an operational definition of dyslipidemia. Dyslipidemia was defined as an abnormality in lipid levels or using lipidlowering drugs in this study.Ostfeld $\mathrm{R}$ et al. ${ }^{4}$ stated that there were $41 \%$ of the population in the study who were categorized as dyslipidemia but did not explained how many of them that used lipid-lowering drugs.

Yang $D$ et $\mathrm{al}^{8}$ exclude patients who use lipid-lowering drugs while 3 other studies did not include lipid-lowering drugs as confounding variables. Different from those studies, statin as lipid-lowering drugs were used as confounding variables in this study and subdivided based on their intensity into low, medium and high intensity statin.

The results of this study showed that when triglycerides was used as a single ratio with $\mathrm{HDL}$, the predictive value for CAD is better. This is consistent with the Asia Pacific Cohort Studies Collaboration who said that the TG/HDL ratio is better than triglycerides alone in predicting the risk of CAD. ${ }^{9}$ This can be explained because the $T G / H D L$ ratio describes the presence of sdLDL in the body where the sdLDL is a more atherogenic LDL subfraction. ${ }^{10-13}$

Dyslipidemia has been known for a long time as an important risk factor for CAD. Dyslipidemia is associated with the incidence, formation and progression of atherosclerotic plaques. Dyslipidemia can be in form of increase in levels of LDL, an increase in triglyceride levels, or a decrease in HDL levels. Strong evidence suggests increased LDL levels in plasma can lead to the development of CAD. ${ }^{8}$ In the past 25 years an increase in triglyceride levels was considered a risk factor for CAD similar with LDL. But many studies after that did not support the idea. One of those studies is Emerging Risk Factors Collaboration that involved a population of 302,430 from 68 prospective long-term studies with 12785 cardiovascular events. This study showed that an increase in fasting and not fasting triglycerides were associated with an increased risk of CAD after adjusting for age and sex. But this association was attenuated after adjustment for HDL levels and abrogated after additional adjustment with non-HDL cholesterol (cholesterol in LDL and remnants combined). This is in accordance with the opinion which states that what causes CAD is the cholesterol content in remnant particles rather than raised triglycerides. ${ }^{14}$

In recent years, several studies have suggested that an increase in triglycerides and a decrease in HDL is a form of atherogenic dyslipidemia. Triglycerides or HDL alone does not always describe the overall cardiovascular risk it has, whereas when combined between triglycerides and $\mathrm{HDL}$ to be a single ratio, it will have a better power to predict cardiovascular disease. ${ }^{12}$

$\mathrm{TG} / \mathrm{HDL}$ ratio is a novel lipoprotein index which indicate the presence of sdLDL. ${ }^{5}$ Hanak $V$ et $\mathrm{al}^{10}$ in their study reported that a TG/HDL ratio of 3.8 had a strong correlation with LDL particle size. Based on other studies conducted by DobiasovaM et $\mathrm{al}^{11}$ it was found that TG/HDL log were associated with LDL particle size where the TG/HDL log value of 0.066 became the cutoff point between LDL size $\leq 25.5 \mathrm{~nm}$ (atherogenic pattern type B) with LDL size> $25.5 \mathrm{~nm}$ (type A). Based on another study conducted by Maruyama $C$ et $\mathrm{al}^{13}$ it was also found that there was a relationship between the TG/HDL ratio and small LDL particles in a healthy nondiabetic population.

Small dense LDL particles (sdLDL) is more atherogenic compared to larger LDL particles. ${ }^{5,10,15-17}$ Based on a study by Moon JY et $\mathrm{al}^{18}$ there was a significant association between sdLDL and the severity of coronary lesions calculated using Gensini score. Another study conducted by Kwon SW et al ${ }^{19}$ reported that 
sdLDL was associated with the degree of severity of coronary lesions. Based on these data, sdLDL has been shown to be associated with progression and severity of coronary artery lesions in CAD patients.

SdLDL measurements can be done in a variety of ways but those measurements are technically demanding, expensive, and slow to produce the results so the TG / HDL ratio can be used as an alternatives that is faster, easier, cheaper, and widely available. $5,10,13$

This study showed that cardiovascular risk factors such as age, sex, obesity, hypertension, smoking, and metabolic syndrome did not have a significant effect on the TG/HDL ratio and Gensini score. This suggests that atherosclerosis risk factors that were previously considered as confounders in this study did not interfere with the relationship between the TG/HDL ratio and the degree of coronary lesion severity based on the Gensini score.

There are several limitations in this study. Not all of the CAD risk factors that could also affect coronary lesion burden can be controlled in this study. Also other lipid ratios, triglyceride, and $\mathrm{HDL}$ were not included as variables in this study because of the small sample size. Due to the design of this study, further analysis through a prospective cohort study is needed to explain whether a high TG/HDL ratio is the cause of the CAD.

\section{CONCLUSION}

There was a positive correlation between the TG/HDL ratio and the severity of coronary lesions based on Gensini scores in non diabetic stable angina pectoris patients $(r=0.637, p<0.001)$. The higher the TG/HDL ratio, the higher the Gensini score. An increase of TG/HDL ratio of 1 will increase the Gensini score by 22 .

\section{ACKNOWLEDGEMENT}

I express my gratitude to dr. Gugun Iskandar, SpJP and dr. Irwan Lubis, SpJP from Hasna Medika Hospital for their assistance and support on my research.

\section{DISCLOSURES AND ETHICS} study.

No potential conflict of interest in this

\section{REFERENCES}

1. Aboyans V., Ricco J.B., Bartelink M.E.L., Bjorck M., Brodmann M., et al. 2018 ESC Guidelines on the Diagnosis and Treatment of Peripheral Arterial Diseases, in collaboration with the European Society for Vascular Surgery (ESVS). Eur J Vasc Endovasc Surg, 55(3):305-368.

2. Gibbons R.J., Abrams J., Chatterjee K., Daley J., Deedwania P.C., Douglas J.S., et al. 2003. ACC/AHA 2002 guideline update for the management of patients with chronic stable angina-summary article: a report of the American College of Cardiology/American Heart Association Task Force on practice guidelines (Committee on the Management of Patients With Chronic Stable Angina). J Am Coll Cardiol, 41(1):159-168.

3. Okrainec K., Banerjee D.K., Eisenberg M.J. 2004. Coronary artery disease in the developing world. Am Heart J, 148(1):7-15.

4. Ostfeld R., Mookherjee D., Spinelli M., Holtzman D., Shoyeb A., Schaefer M., et al. 2006. A triglyceride/high-density lipoprotein ratio $>$ or $=3.5$ is associated with an increased burden of coronary artery disease on cardiac catheterization. J Cardiometab Syndr, 1(1):13-15.

5. Conkbayir C., Ayca B., Okcun E.B. 2015. Lipid variables related to the extent and severity of coronary artery disease in non-diabetic Turkish Cypriots. Iran J Public Health, 44(9):1196-1203.

6. Luz P.Ld., Favarato D., Junior J.R.FN., Lemos P., Chagas A.C.P. 2008. High ratio of triglycerides to HDLcholesterol predicts extensive coronary disease. clinics, 63:427-432.

7. Hadaegh F., Khalili D., Ghasemi A., Tohidi M., Sheikholeslami F., Azizi F. 2009. Triglyceride/HDL-cholesterol ratio is an independent predictor for coronary heart disease in a population of Iranian men. Nutr Metab Cardiovasc Dis, 19(6):401-408.

8. Yang D., Liu X., Xiang M. 2011. The correlation between lipids ratio and degree of coronary artery stenosis. High Blood Press Cardiovasc Prev, 18:53-56. 
9. Barzi F., Patel A., Woodward M., Lawes C.M., Ohkubo T., Gu D., et al. 2005. A comparison of lipid variables as predictors of cardiovascular disease in the Asia Pacific region. Ann Epidemiol, 15(5):405-413.

10. Hanak V., Munoz J., Teague J., Stanley A.Jr., Bittner V. 2004. Accuracy of the triglyceride to highdensity lipoprotein cholesterol ratio for prediction of the low-density lipoprotein phenotype B. Am J Cardiol, 94(2):219222.

11. Dobiasova M., Frohlich J. 2001. The plasma parameter log (TG/HDL-C) as an atherogenic index: correlation with lipoprotein particle size and esterification rate in apoB-lipoproteindepleted plasma (FER(HDL)). Clin Biochem, 34(7):583-538.

12. Giorgis T.D., Mohn A. 2014. Could the triglyceride:HDL cholesterol ratio be considered a new marker of cardiovascular risk in obese children? Clin Lipidol, 9(1):1-3.

13. Maruyama C., Imamura K., Teramoto T. 2003. Assessment of LDL particle size by triglyceride/HDL-cholesterol ratio in non-diabetic, healthy subjects without prominent hyperlipidemia. $\mathrm{J}$ Atheroscler Thromb, 10(3):186-191.

14. Nordestgaard B.G., Varbo A. 2014. Triglycerides and cardiovascular disease. Lancet, 384(9943):626-35.
15. Tornvall P., Karpe F., Carlson L.A., Hamsten A. 1991. Relationships of low density lipoprotein subfractions to angiographically defined coronary artery disease in young survivors of myocardial infarction. Atherosclerosis, $90(1): 67-80$.

16. Stampfer M.J., Krauss R.M., Ma J., Blanche P.J., Holl L.G., Sacks F.M., et al. 1996. A prospective study of triglyceride level, low-density lipoprotein particle diameter, and risk of myocardial infarction. JAMA, 276(11):882-888.

17. Gardner C.D., Fortmann S.P., Krauss R.M. 1996. Association of small lowdensity lipoprotein particles with the incidence of coronary artery disease in men and women. JAMA, 276(11):875881.

18. Moon J.Y., Kwon H.M., Kwon S.W., Yoon S.J., Kim J.S., Lee S.J., et al. 2007. Lipoprotein(a) and LDL particle size are related to the severity of coronary artery disease. Cardiology, 108(4):282-289.

19. Kwon S.W., Yoon S.J., Kang T.S., Kwon H.M., Kim J.H., Rhee J., et al. 2006. Significance of small dense lowdensity lipoprotein as a risk factor for coronary artery disease and acute coronary syndrome. Yonsei Med J, 47(3):405-414. 